\title{
37. SUMMARY OF THE EVIDENCE FOR EXTENSIONAL AND COMPRESSIONAL TECTONICS IN THE MEDITERRANEAN
}

\author{
Kenneth J. Hsü, Geologisches Institut, Eidg., Technische Hochschule, Zurich, Switzerland \\ and \\ William B. F. Ryan, Lamont-Doherty Geological Observatory of Columbia University, Palisades, New York
}

\section{INTRODUCTION}

The most significant results of the two month cruise of the Glomar Challenger into the Mediterranean will come from detailed studies of the hundreds of meters of recovered sediments and rocks obtained from a total of twenty-eight holes drilled at fifteen locations. As has turned out to be the case for so many of the expeditions of the Deep Sea Drilling Project, a few of the preliminary findings have confirmed earlier working hypotheses, but so many more have turned up new puzzles and surprises.

The preliminary interpretations of the geological results of each drill site are treated in the individual site reports of Part I of this volume. The intention of this present chapter is to summarize highlights of these site reports in a somewhat broader perspective. The main problems to be considered are new implications derived from drilling concerning the genesis and ages of the various Mediterranean basins, and the new evidence concerning compressional tectonics of the sea bed. More specialized investigations of lithostratigraphic and biostratigraphic findings and problems are treated in subsequent chapters.

\section{GENESIS OF THE WESTERN MEDITERRANEAN BASINS}

One of the goals most often mentioned in precruise site planning was determination of the age of the various Mediterranean basins. Implicit in this objective was the direct sampling of bedrock so as to shed light on its origin and method of emplacement.

Proposed methods to determine the age by deep-sea drilling included recovery of the deepest (oldest) sediment above bedrock. This strategy does not suffice, however, for vast areas of the deeper parts of the Mediterranean basins, where the total thickness of the sedimentary layer considerably exceeds the maximum length of the drill string, which the Glomar Challenger, with her present technology, can utilize.

As a consequence, variants of this scheme were required. One such variant successfully employed during Leg 13 was to first find places where deeply buried (and therefore unreachable) strata could be recognized in the center of a basin or topographic depression. These are observed as discrete reflecting interfaces with the seismic reflection profiler. The reflectors are then traced in continuous profiles onto the flanks of shallower subsurface structural highs. If reasonable arguments can be summoned which indicate that the reflecting surfaces are not likely to be diachronous horizons, then some confidence can be placed in the deduction that the dating of the subbottom strata on the structural high is representative for the regional basin.

Another scheme, which is somewhat less reliable, is to discover a geographic setting where localized submarine erosion at some time in the past either cut deeply into subbottom strata, thus thinning the sedimentary sequence, or left remnants of this erosion (gravels, conglomerates, winnowed sand, etc.) as an identifiable deposit which can be drilled into and sampled. Then by a careful statistical inventory of the recovered material an estimate of at least a minimum age can be obtained for the layering. If samples of the acoustic basement can be obtained either as in situ bedrock or allochthonous components, the sample can be dated, independent of stratigraphic position, by radiometric methods.

The least reliable scheme is to initially drill as deep as possible into thick sequences and then determine a mean rate of sediment accumulation and corresponding interval compressional wave velocities for the section successfully penetrated. This allows eventual extrapolation of the established age-gradient downward to the subbottom level of the acoustic basement. The serious drawback to this approach is that a tacit assumption of a constant sedimentation rate must be made for a sequence of sediment that one has no direct knowledge of, not to mention that one has to speculate that the acoustic basement is indeed the bedrock and not some intermediate horizon.

Using one or more of the aforementioned schemes, age estimates have been arrived at for the basement at Site 120Gorringe Bank, Site 121-Western Alboran Basin, Sites 122 and 123-Valencia Trough, and Sites 133 and 134-Western Sardinia slope and Balearic Abyssal Plain. Unfortunately, no knowledge is available from drilling of the older sedimentary layers in the eastern Mediterranean, nor of the preevaporite sediments (if any) of the Tyrrhenian Basin. Luckily, there are excellent outcrops, in both these regions, of deep strata and possible bedrock which can hopefully be sampled some day soon by conventional dredging and piston coring techniques. Because of the likelihood of success in such ventures, Glomar Challenger drilling time was not spent on these objectives.

\section{Age of the Oceanic Bedrock on the Iberian Plate West of Portugal}

Direct drilling into bedrock was effected at Site 120 on the northern flank of Gorringe Bank. The setting of this drill hole north of the Azores-Gibraltar tectonic boundary (Le Pichon et al., 1970; McKenzie, 1970) is documented in Chapter 2. The site lies about $120 \mathrm{~km}$ west of the edge of the Iberian continental margin on a piece of sea floor crust 
believed to have been accreted as the Iberian Plate rotated away from the North American Plate, to which Europe was still attached at that time. (See discussions in Williams and McKenzie, 1971; and Pitman and Talwani, 1972.)

Site 120 was purposely located on a topographic high where some of the thick sedimentary sequence found in the adjacent Tagus Abyssal Plain to the north had been removed through gravity sliding (Figure 1). Basement rock (spilitic basalt and metagabbro) was encountered beneath pelagic marls and some chert containing fossil tests diagnostic of a Lower Cretaceous (Barremian) age. The stratigraphic identification is documented in Chapter 34.1 for the siliceous microfossils and Chapter 41.1 for the assemblages of foraminifera.

Although some 14 meters of uncored section lie between the lowermost sample of sediment and the first recovered pieces of the igneous rock, an estimate of uniform rates of sedimentation $\left(\approx 0.4 \mathrm{~cm} / 10^{3} \mathrm{y}\right)$, derived from a sequence of five consecutive Lower Cretaceous cores, allow us to reasonably extrapolate a minimum age of approximately 120 my for this piece of crust. Such an age assignment agrees with independent assessments of the timing of rotation of the Iberian Plate with respect to Europe, derived both from measurements of fossil rock magnetism (Stauffer and Tarling, 1971) in Spain and Portugal, and by the distribution of marine magnetic anomalies in the Bay of Biscay (Le Pichon and Sibuet, 1971).

Since Site 120 lies some distance from the edge of the continent, we extrapolate an early Cretaceous age of perhaps 130 my for the initial rifting of Iberia from North America and Europe-an event which created the northeastern Atlantic Ocean west of Portugal and the Bay of Biscay.

\section{Age of the Bedrock in the Western Alboran Basin}

Deeply buried strata of the western Alboran Basin could not be directly sampled by the Glomar Challenger during this first reconnaissance cruise. Nevertheless, a most interesting site was found in this basin where a wide range of scientific objectives could be pursued with a single exploratory hole, and where it was believed reasonable estimates would be given as to the age of the deep strata.

Figure 2 shows a north-south reflection profile at the base of the continental rise of Spain in the western Alboran Basin. Site 121 is located over the northern flank of a buried basement ridge. Drilling there recovered a suite of metamorphic rocks whose petrology and trace element composition is presented in Chapter 27. An apparently good quality radiometric date was determined $(16.0 \pm 1.0$ my) on biotite from one of the garnet-bearing micaceous gneisses. Since the deeper strata to the north and south of the ridge all onlap against the ridge, this age determination of the bedrock can be taken as a maximum value for all the layering seen in this reflection profile. The oldest sediment actually penetrated at the drill hole is observed to be unconformable on the basement and has been identified as Upper Miocene (Tortonian) in stratigraphic age (perhaps 10 or 11 my according to Berggren, 1972).

\section{The Age of the Bedrock in the Valencia Trough}

A similar situation of protruding basement highs also exists in the region of the Valencia Trough north of the
Balearic Islands in the western Mediterranean. Again, these ridges seem to belong to the basin bedrock since much of the deeper layer of the Balearic Abyssal Plain can be seen to progressively onlap its uppermost surface in seismic profiles directed from the abyssal plain up the trough. (Formations C and D of Montadert et al., 1970, and Couches II and III of Auzende et al., 1971). Sites 122 and 123 were positioned over two such subsurface highs. Although the first of these holes was terminated before penetrating the level of the acoustic basement, it did recover a massive gravel bed on the upper surface of the Mediterranean evaporite layer. The gravel contains numerous fragments of volcanic rocks including vesicular and aphanitic basalt (see Chapter 4). The gravel is of a very unusual composition which we consider geologically significant. Accompanying the basalt one finds exclusively pieces of the evaporite (gypsum), shallow water fauna associated with the evaporite, and preevaporite deep-sea limestones. The limestone pebbles have fossil ages ranging from Upper Miocene (Tortonian) to Middle Miocene (Langhian).

If we conjecture that the gravel derives from erosion of the Valencia Trough sea bed during Late Miocene times (i.e., during the evaporite epoch of Messinian Age) because no younger sediment or lithic rock components (continentally derived) were recognized, we might expect that the cutting into bedrock which produced the volcanic fragments would have left debris of the overlying strata as well. Perhaps the Langhian limestones are the initial deep sea sediment on this basement terrain.

At Site 123, a few tens of kilometers further down the axis of the Valencia Trough from Site 122, a window in the sedimentary cover above acoustic bedrock was found (Figure 3). Here the drill string had no difficulty in reaching basement; it was subsequently penetrated for over 125 meters, where more volcanic materials were obtained. This larger sampling permitted radiometric ages to be ascertained giving values of $\approx 19$ to $22 \mathrm{my}$, slightly older than the aforementioned Langhian age estimate. Because Formation D, Couche III, and the N-Reflectors (discussed in Chapters $4,5,6$, and 14) all transgress onto the flank of the basement ridge at Site 132 , we tentatively conclude that where they are present further east in the Balearic Abyssal Plain the basement there must be at least Lower Miocene (Burdigalian) in age.

Drilling at Site 134 permitted the direct sampling of a buried nonmagnetic basement ridge at a structural boundary where the western Sardinia continental slope is transgressed by thick sediments of the Balearic Abyssal Plain.

Penetration into the basement was achieved at five offset holes, and metagraywackes and phyllites were obtained (Chapter 14). Investigations of these rock samples, documented in Chapter 29, suggest that they are of Lower Paleozoic age and are correlative to outcrops of CambrianOrdovician sedimentary strata in southwestern Sardinia. The drilling at Site 133 in a slope basin just to the east of the crest of the basement ridge there was able to show that both the M-Reflectors and subadjacent deeply buried $\mathrm{N}$-Reflectors were deposited during desiccated phases of the Late Miocene evaporite epoch. This result allows us to propose a much greater thickness for the Mediterranean 

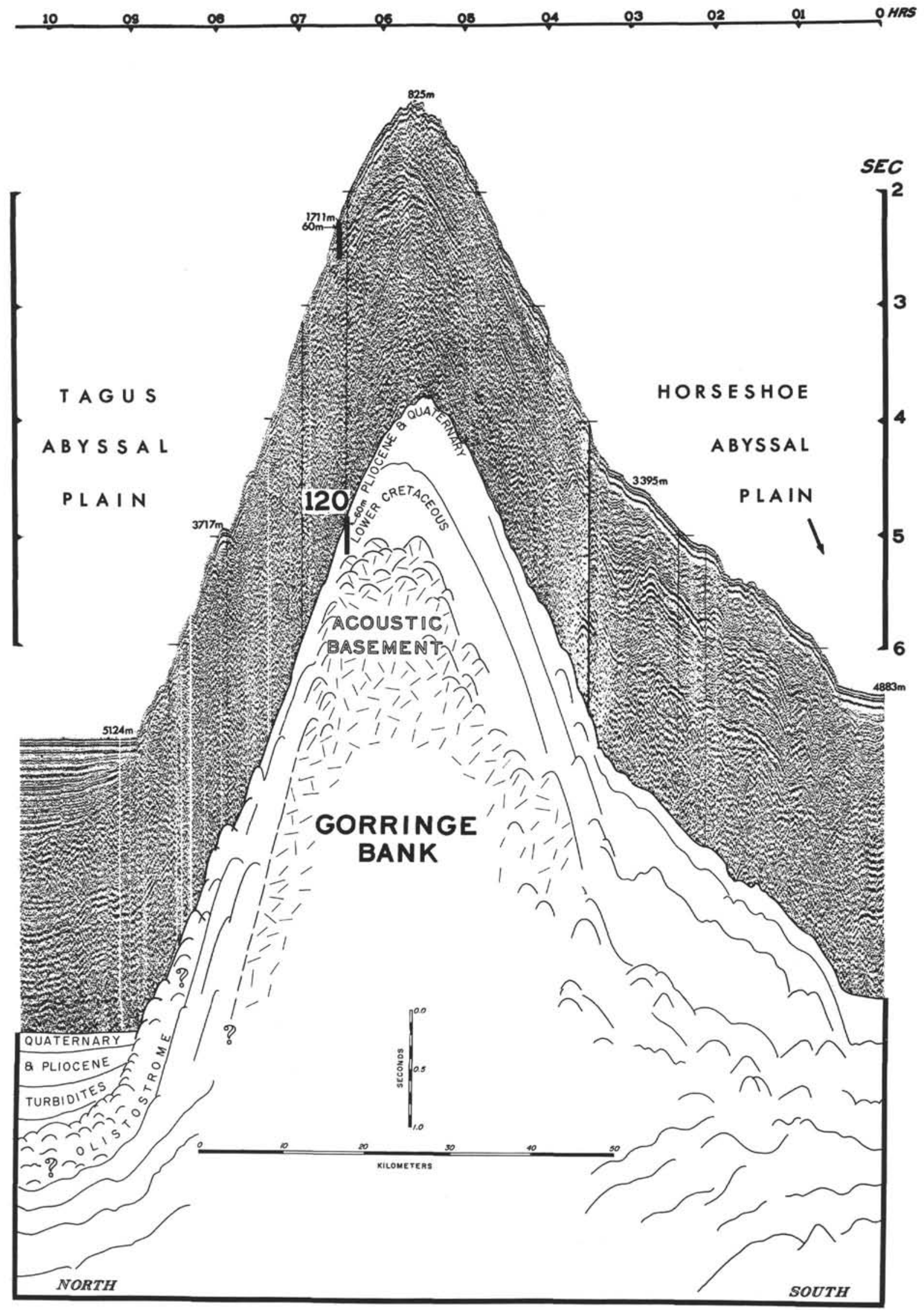

Figure 1. Reflection profile of the Jean Charcot across Gorringe Bank in the eastern North Atlantic. Note thinning of the sedimentary sequence at Site 120 and the possible olistostrome talus beneath the Tagus Abyssal Plain. 


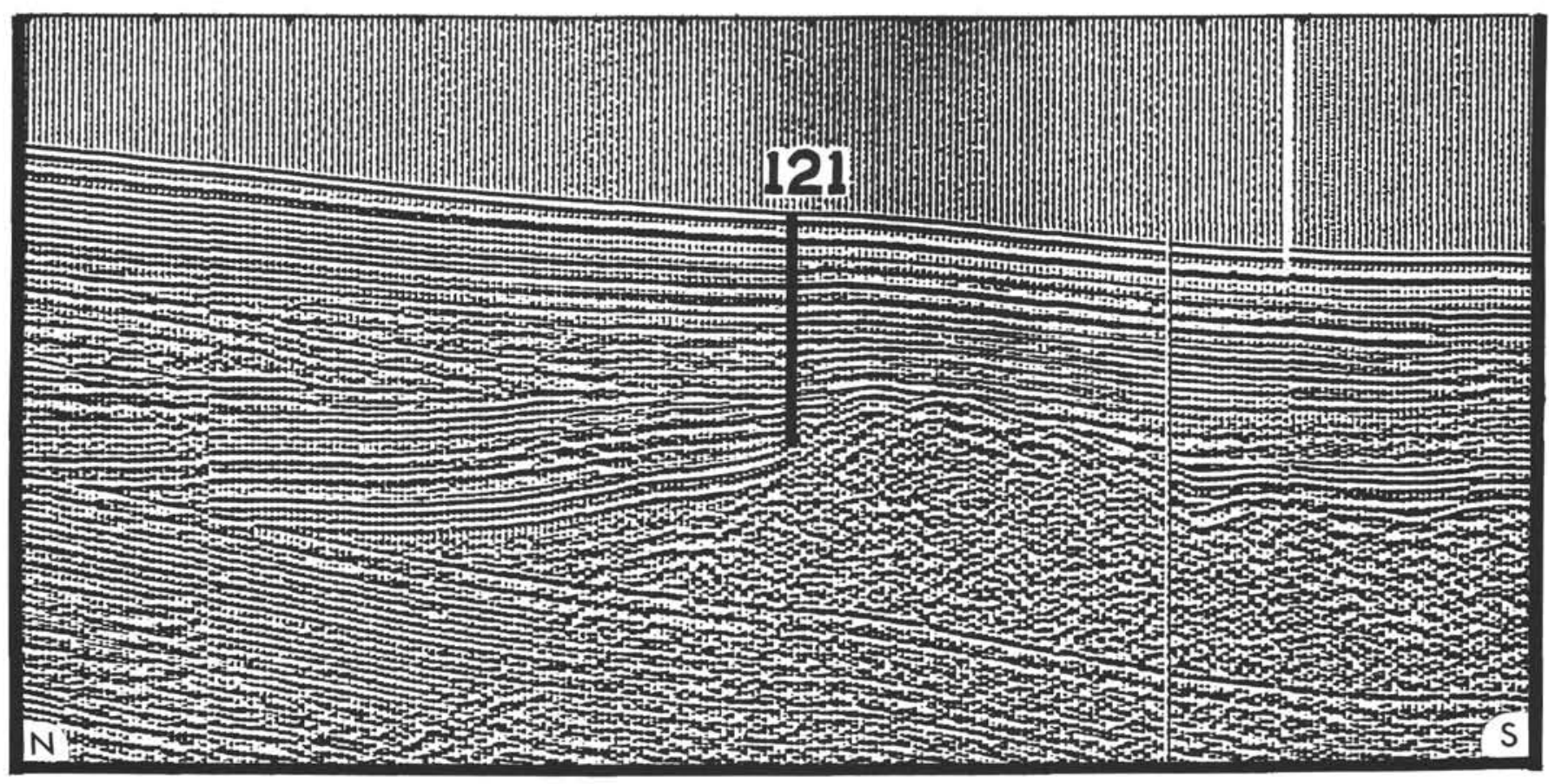

Figure 2. North-south reflection profile of the Jean Charcot across a buried basement ridge in the western Alboran Basin. See Chapter 3 for location of this profile. Note the onlapping of deeper strata against this structural high.
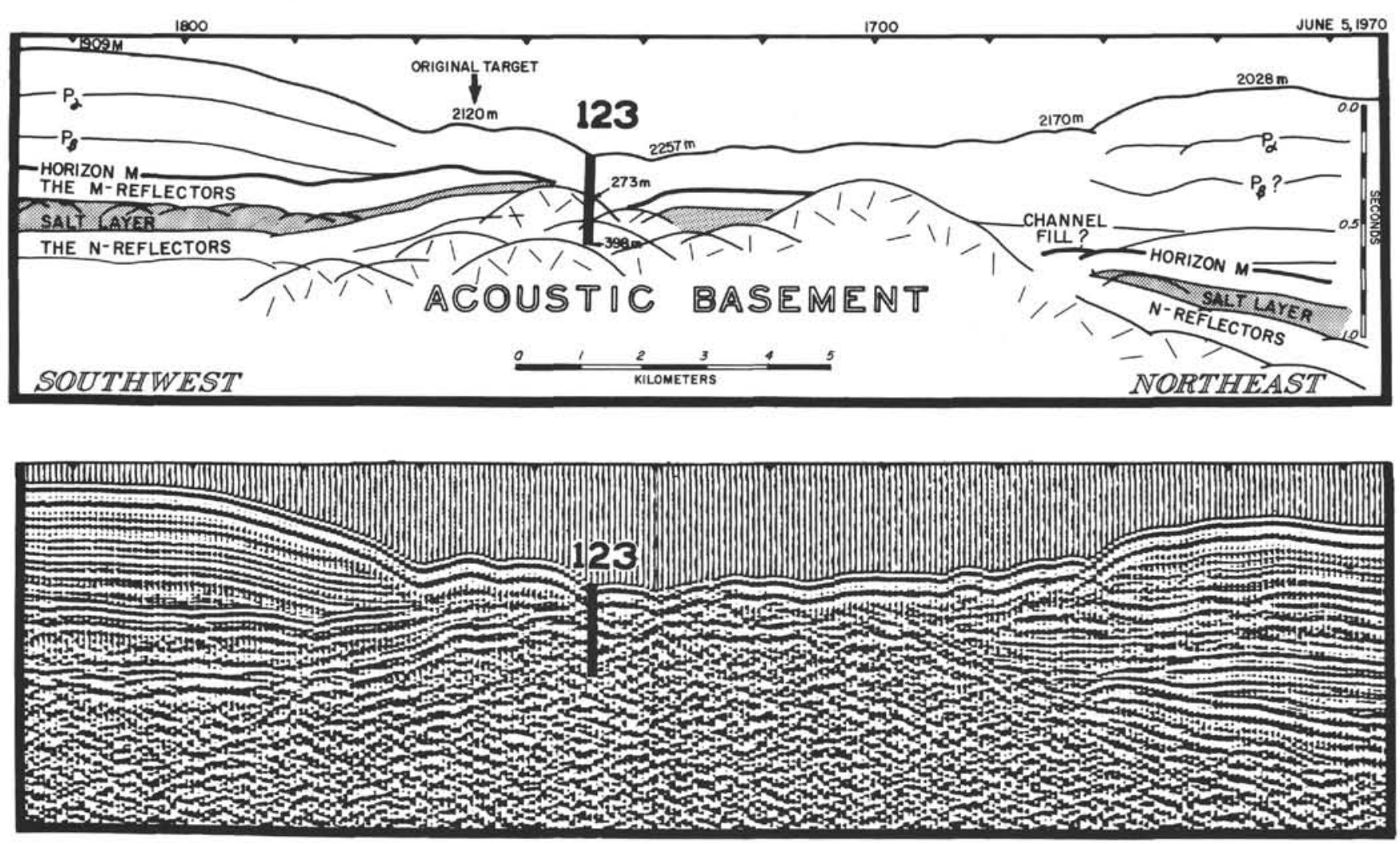

Figure 3. Reflection profile and its interpretation across a window in the sedimentary blanket at Site 123 in the Valencia Trough. The basement of andesitic volcanic materials was penetrated from 273 to 398 meters below bottom. 
evaporite than previously suggested (see Montadert et al., 1970; Auzende et al., 1971; Le Pichon et al., 1971).

General Age Estimate for the Initial Extension of the Western Mediterranean

The radiometric age of 19 to 22 my for the outpouring of the Valencia Trough volcanic substratum (at least in the vicinity of the marked magnetic anomalies of the axial portion of the Trough where the drill sites were located) indicates a youthful genesis of this part of the Mediterranean. Since the magnetic anomaly pattern extends up the southern margin of France as well as along the western margin of Sardinia and Corsica, it is possible to link the development of all the anomalies to a single episode of igneous activity during early rifting phases. This argument is elucidated at greater length in Chapter 14. It suffices to say here that radiometric dates on Tertiary volcanics in Spain, along the Côte d'Azur, and in Sardinia are not inconsistent with an early Miocene (Burdigalian stage) episode of rifting of the Balearic Basin and Valencia Trough by the rotation of small microplates (Alvarez, 1972). It seems to us that the Middle Oligocene date given by Le Pichon et al. (1971) for this event is perhaps a little too old, being derived in part by an underestimate of the thickness of the evaporite layer (Figure 4) and consequently an overestimate of the age duration of the preevaporite deep strata overlying the acoustic basement.

\section{NEW EVIDENCE CONCERNING COMPRESSIONAL TECTONICS}

One of the main objectives of the drilling program in the eastern Mediterranean was to explore the nature in which the sea floor carpet of sediment is deformed as its lithospheric substratum is underthrust and consumed at subduction zones in oceanic trenches. Sites 127, 128, and 129 are all located over the floors of deep trenches rimming the Hellenic Island Arc, whereas Site 130 was chosen seaward of the trench on the upwarped Mediterranean Ridge.

\section{Discussion of the Hellenic Trench Results}

Two sites were located on the narrow flat-floored plain of the Hellenic Trench west of Crete, one near the inner trench-wall and one near the outer wall. At the former Site (127), three individual holes were drilled on a northeastsouthwest line. The first was on the trench plain at a distance of 470 meters seaward of the inner-wall contact; the second $(127 \mathrm{~A})$ was located 130 meters beyond the contact on the inner wall, and the third (127B) was then located close to the contact, about 40 meters seaward of it. Site 128 was aligned along the same line $3.4 \mathrm{~km}$ further to the southwest (see Chapter 9 for details of the geological and tectonic setting).
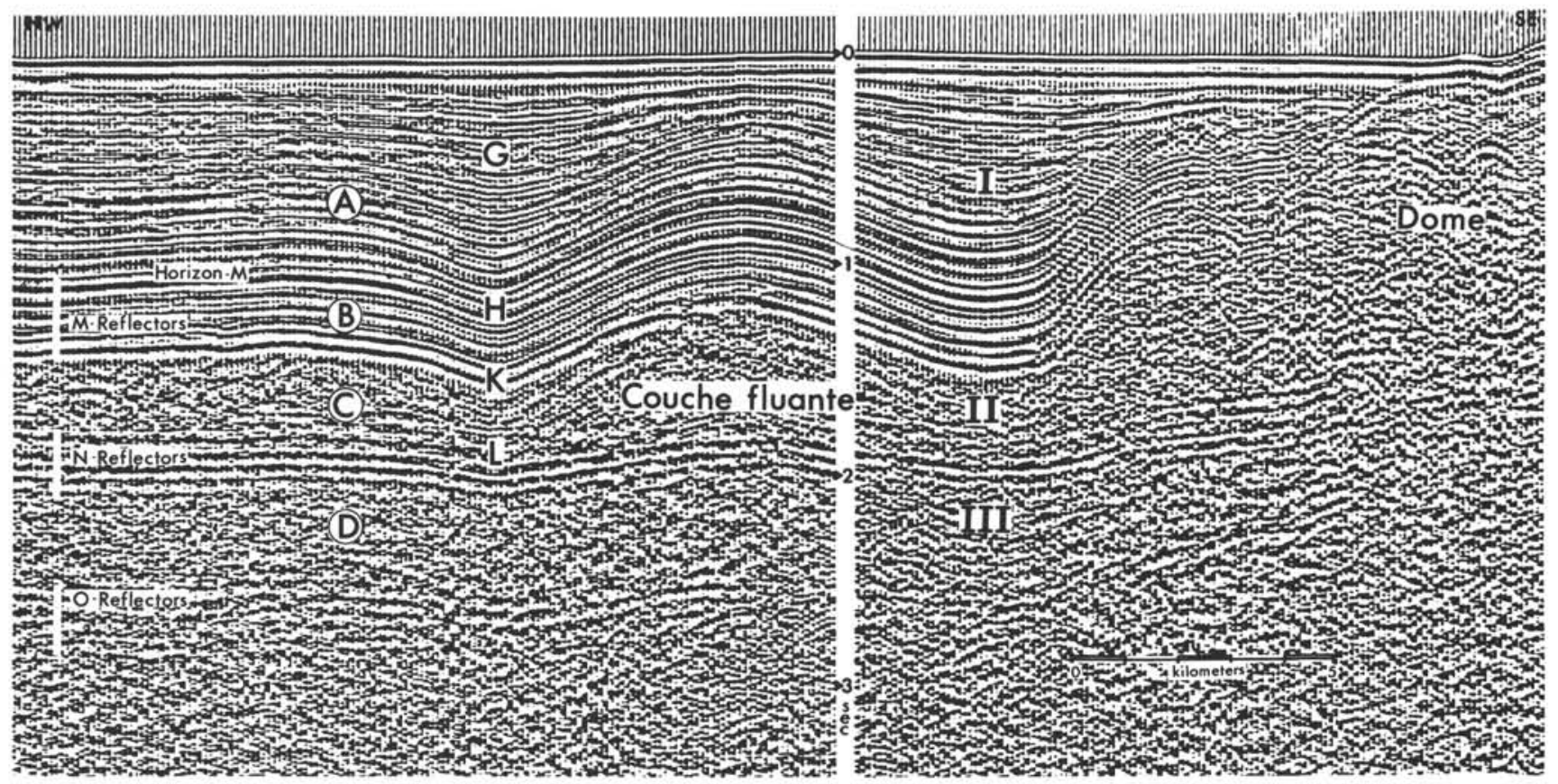

Figure 4. Seismic reflection profile of the Jean Charcot in the region of the Valencia Trough, western Mediterranean. Originally only Formation $C=$ Bed II was identified as the salt layer (Montadert et al., 1970; Auzende et al, 1971; Le Pichon et al., 1971). The layer marked "couche fluante" was recognized by its flowing nature in the development of the anticlinal structures (center) and piercement diapirs (right). However, a refraction profile of Fahlquist and Hersey (1969) which crosses this reflection profile shows that the deeply buried O-Reflectors have a compressional-wave velocity of $4.92 \mathrm{~km} / \mathrm{sec}$, a value very close to that directly measured on the recovered sulfate facies of the evaporite formation. Drilling also revealed the M-Reflectors to be part of this evaporite layer. At Site 133 the N-Reflectors were penetrated and comprised alluvial fanglomerates of inferred Messinian age. Since Formation D = Bed III has a markedly similar acoustic signature to Formation $C=$ Bed II, it may be that the evaporite layer actually reaches 2 to $3 \mathrm{~km}$ in total thickness here, rather than the original estimate of 600 meters given by Montadert et al., (1970). 
The purpose of drilling near the inner wall was to find out if this feature corresponded to a crumpled pile of sediment scraped from the converging ocean floor crust. Lower Cretaceous limestones and dolomites were subsequently encountered in all three of the holes at Site 127, along a steeply inclined horizon dipping about 30 degrees southwest towards the trench axis. Younger Neogene pelagic oozes were encountered mixed with, and lying below, the Cretaceous rocks.

In Hole 127, a horizontally bedded Upper Pliocene ooze is present at 435 meters below bottom, some 8 meters below the Cretaceous/Quaternary contact. This ooze is a normal deep-sea pelagic sediment, and contains no exotic elements. In Holes 127A and 127B, the ooze has been lithified and partially recrystallized and is found between brecciated fragments of the Lower Cretaceous limestones and dolomites.

The three holes were terminated at 437 meters, 80 meters, and 166 meters below bottom, respectively, shortly after the Lower Cretaceous carbonates were reached. Termination of the drilling was necessitated because of low penetration rates (it took, for example, four hours to drill through 1 meter of the dolomite in Hole 127). Although the deepest subbottom sample from Hole 127 is Upper Pliocene ooze, the hole must have actually bottomed in a lithified rock (presumably the Cretaceous carbonates) in view of the very slow drilling rate during the last several hours of the operation. A few other brief intervals of apparently fast drilling rates were also noted while grinding away in the limestone formation. It is probable that some other intervals of soft oozes are present below the Quaternary-Cretaceous contact, but they were not recovered by coring.

No Lower Cretaceous carbonates were encountered in Hole 128 near the southwestern outer wall of the Hellenic Trench.

\section{Olistostrome or Mélange?}

The Lower Cretaceous carbonate rocks belong to a shelf facies and are indicative of shallow-marine depositional environment (see Chapters 9 and 41.2). Now they are present at a subsea depth of some 5000 meters. Obviously, there has been a large vertical displacement. Is this displacement tectonic or sedimentary?

The intimate mixture of the Cretaceous rocks with the Neogene oozes is clear evidence that we have drilled into a zone of mixed rocks. Two different sets of geological processes could lead to stratal disruption and to mixing. In a tectonic mélange, the fragmentation and mixing are directly related to shearing and disruption of generally deeply buried units. The disintegration of a formation into large blocks and mixing of such blocks with muds could have also resulted from sedimentary processes, such as submarine sliding. A distinction between these two genetically different types of mixed rocks is, in many ways, difficult (Hsü, 1968).

Numerous colleagues, including some of our shipmates, favor the idea of an olistostrome. We could not have been that lucky, as the argument went, to have actually penetrated a zone of underthrusting as we had hoped to do. Rather, it seemed more logical and less incredulous to assume that we merely drilled into a thick breccia bed or an olistostrome at the foot of a very steep trench wall. The shelf Cretaceous carbonates were slumped into the trough where they were mixed with Neogene pelagic sediments.

However, the authors of this chapter find no independent evidence exclusively in favor of an olistostrome hypothesis. Olistostromes are lenticular sheets of wide lateral extent, ranging in thickness from a few feet to several hundred feet, and those masses are clearly interbedded in a formation. If we were to have delineated such a sheet-like body intercalated in trench sediments, by drilling or by continuous seismic profiling, the evidence would then be overwhelmingly in favor of the postulate of sedimentary mixing. We not only failed to encounter a sedimentary breccia a few kilometers further out of the trench plain at a comparable stratigraphic level in the sediment column, but we must point out that the Cretaceous rocks recovered at all the Site 127 holes near the inner wall were diachronously transgressed by younger and younger Quaternary trench fill in the landward direction along the transit. Furthermore, the limestones are not intercalated in the trench fill, but lie on a major time unconformity above deep-sea pelagic oozes. The seismic profiling record does not reveal the presence of any sheet-like sedimentary body which could be traced laterally beneath the plain. In fact, the profile only shows that the top of the mixed zone is the subsurface extension of the steep inner trench-wall generally identified as acoustically opaque.

The nature of the matrix also speaks against a depositional origin. Whereas the matrix of an olistostrome tends to be poorly sorted in size and in composition, the matrix of the Hellenic Trough Cretaceous-Pliocene zone has entirely uncontaminated assemblages of fauna and no recognizable exotic elements. The matrix of an olistostrome tends to be chaotically bedded, but the Upper Pliocene ooze encountered in Hole 127 is horizontally laminated. The blocks in an olistostrome are rimmed by a sedimentary contact, often with a rolled "snowball" appearance. The Pliocene ooze in Hole 127, in contrast, is bounded by a steep-dipping fracture plane from the overlying carbonate rock. Fragments of the limestones and dolomites show cataclastic textures and shear planes into which the ooze has penetrated.

The Quaternary stratigraphy of the trench-sediments also gives no indication that there should have been such an Upper Pliocene olistostrome. An olistostrome is a part of a sedimentary sequence and has conformable contacts with the overlying sediments. Yet the mixed-zone under the trench wall is not conformable with the overlying sediments. The matrix has an age belonging to the lower part of the Upper Pliocene, and the overlying sediments are late Quaternary in Hole 127A, and early Quaternary in Hole 127 . None of the cores record a gradual change from an earlier regime of olistostrome deposition to a later regime of trench sedimentation.

A most critical observation concerns the dip angle of the Quaternary-Cretaceous contact. The slope of this contact between Holes 127A and 127 is 32 degrees. The maximum angle of repose of talus deposits approaches this value only in the subaerial environment and the angle for submarine deposits is perhaps an order of magnitude less (B.C. Heezen, personal communication). 
All of the aforementioned considerations prevented us from adopting as an exclusive working hypothesis the idea that we merely hit an olistostrome in Holes 127, 127 A and $127 \mathrm{~B}$.

\section{Other Evidence for Underthrusting}

The evidence of underthrusting is not supplied exclusively by the drilling results. On the contrary, the hypothesis has been clearly outlined on the basis of geophysical investigations conducted prior to the beginning of the cruise.

The Hellenic Trough belongs to a deep-trench system which fringes an island arc that extends from Peloponnesus to Crete to Rhodes. The apex of the arc points towards Africa. Like other island arcs, the Hellenic Arc is also characterized by belts of negative free-air anomalies (Rabinowitz and Ryan, 1970). The southern negative gravity belt is continuous and represents anomalies associated with the Mediterranean Ridge. The northern belt, interrupted at places by gravity highs, extends more or less along the Hellenic Trough (Figure 5).

The Hellenic Arc also defines a belt of active seismicity, where both shallow and intermediate earthquakes have occurred. The foci of these earthquakes generally fall on a northward dipping Benioff Zone (see documentation in Chapter 9). Behind the Island Arc there is a belt of active andesitic volcanism; farther north is the central Aegean Sea.
The setting of the Hellenic Arc closely resembles that of arcs around the border of the Pacific Ocean (Hayes and Ewing, 1971). These arcs are believed to be sites of active lithospheric subduction. It is reasonable to expect a similar tectonic origin for the Mediterranean tectonic belts.

McKenzie (1970), studying the focal mechanisms of earthquakes beneath the Hellenic Arc, has found apparently good evidence of active thrusting here, with the northerly Aegean Plate being overthrust in a southwest direction over the oceanic basin of the eastern Mediterranean. In fact, this regional tectonic framework provided the very basis of our precruise planning. Indeed, we anticipated the presence of broken formations or mélanges under the trench wall. One of the hypotheses to be tested was the one advanced by Dewey and Bird (1970), who assumed the piling up of severly deformed flysch wedges under the wall. Alternatively, one could assume a rocky wall of deep-sea trenches underlain by a zone of underthrusting, where tectonic mélanges commonly are present (see Hsü, 1971).

Locating the zone of tectonic disturbance was dependent upon precise positioning of the Glomar Challenger. This was achieved by excellent navigation assisted by our colleague, Guy Pautôt, who directed the Challenger above the margin of the trench, where the plane of shearing was predicted to crop out under the Quaternary trench fill.

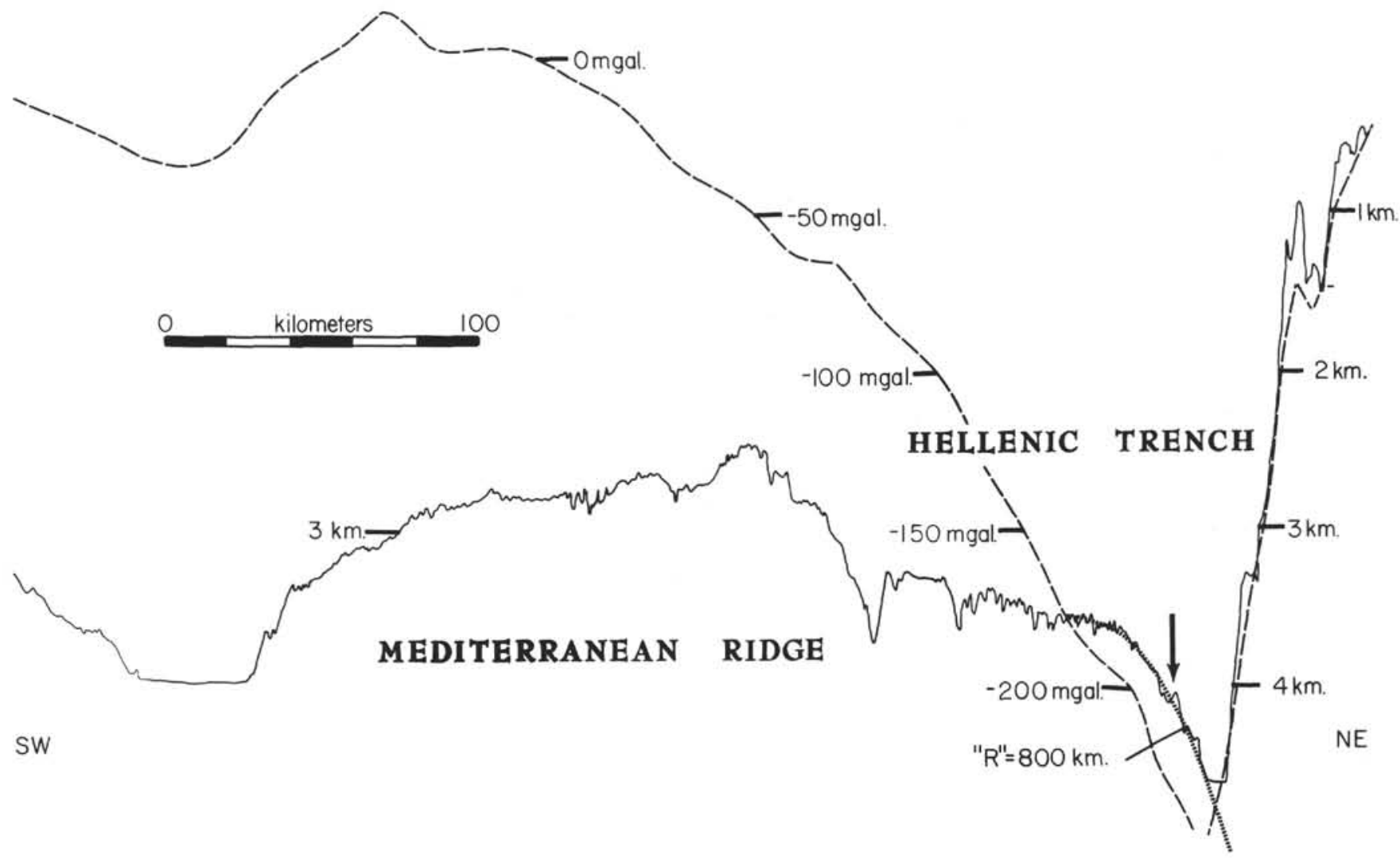

Figure 5. Free-air gravity and bathymetric profiles across the Mediterranean Ridge and Hellenic Trench in the Ionian Basin west of Crete. Sites 127 and 128 were targeted on the flat-floored portion of the trench axis. This profile made by the Robert D. Conrad is a projection around a point (arrow) $35.65^{\circ} \mathrm{N}$ and $22.36^{\circ} \mathrm{E}$ in a direction of 063 degrees (i.e. normal to the strike of the trench). The finely dashed line is a portion of the circumference of a circle. (50:1 vertical exaggeration) with a radius of curvature of $800 \mathrm{~km}$. 
Subsequently, we drilled and found the CretaceousPliocene mixture. For the reasons enumerated, it is unlikely that this mixture is a sedimentary deposit. A more geologically reasonable alternative is that we have actually found the tectonic mélange whose presence had been forecasted on the basis of the geophysical synthesis.

The mélange zone may be only a few tens or few hundred meters thick, as is the case of the Prealpine wildflysch. Or, the bottom of the mélange could be extremely deep, as is the case of the Franciscan mélange of the California coast ranges. We regret that we were not able to penetrate more than 10 meters into this mixed zone, being prevented by considerations of available ship time and by the present unsatisfactory state of drilling techniques. The problem might be reexamined if a future cruise to the Mediterranean would return to the Hellenic Trench and with better drill bits penetrate 100 meters more beneath the top of the mixed zone.

Our explorations in the Hellenic Trench failed to discover a deformed flysch wedge, as postulated by Dewey and Bird (1970). Perhaps a "flysch wedge" might be encountered north of the Hellenic Trench if we had positioned our holes farther up the inner wall.

\section{Quantitative Evidence of the Rate of Consumption}

Two interesting observations were noted in Chapter 9 concerning the nature of the stratified sediment fill in the Hellenic Trench. One is that individual sedimentary beds could be traced across the trench plain from Holes 127B to 127 and then to 128 . The strata dip at gentle but progressively steeper angles with depth toward the landward wall of the trench as was observed on the seismic reflection profile. This is also the case in many trenches around the Pacific Ocean where sediment is present in a recognizable trench plain (Hayes and Ewing, 1971). A stratigraphic dating documented in the Site Report of Chapter 9 shows that tilting of the strata has proceeded during the Quaternary time, represented by the $>480$ meters of fill, at a rate of approximately 1 degree per million years.

Lithologic investigations on the trench cores clearly indicate that the deposition of the stratified trench fill was predominantly the result of ponding by turbidity currents arriving from sedimentary reservoirs higher up on the inner wall. Each episodic flow tends to level any preexisting tilt of the surface of the trench plain at that point in time since a relationship could be established between the relative thickness of individual turbidite layers at the seaward and landward margins of the trench, respectively, and the interval sedimentation rate (see Chapter 9).

We infer that the progressive tilting of the trench plain occurs as the result of a downbowing of the seaward oceanic lithosphere as it flexes over a radius of curvature during the descent along the inclined plane of the seismic Benioff Zone (Figure 6). The angular rate of dip of the trench fill $(d \theta / d t)$ is identical to the angular rate of flexure of the lithosphere around the center of curvature. If we can determine a priori the radius of curvature $R$, then the translation rate of the lithosphere $(d L / d t)$ is proportional to the dip rate by the following relationship:

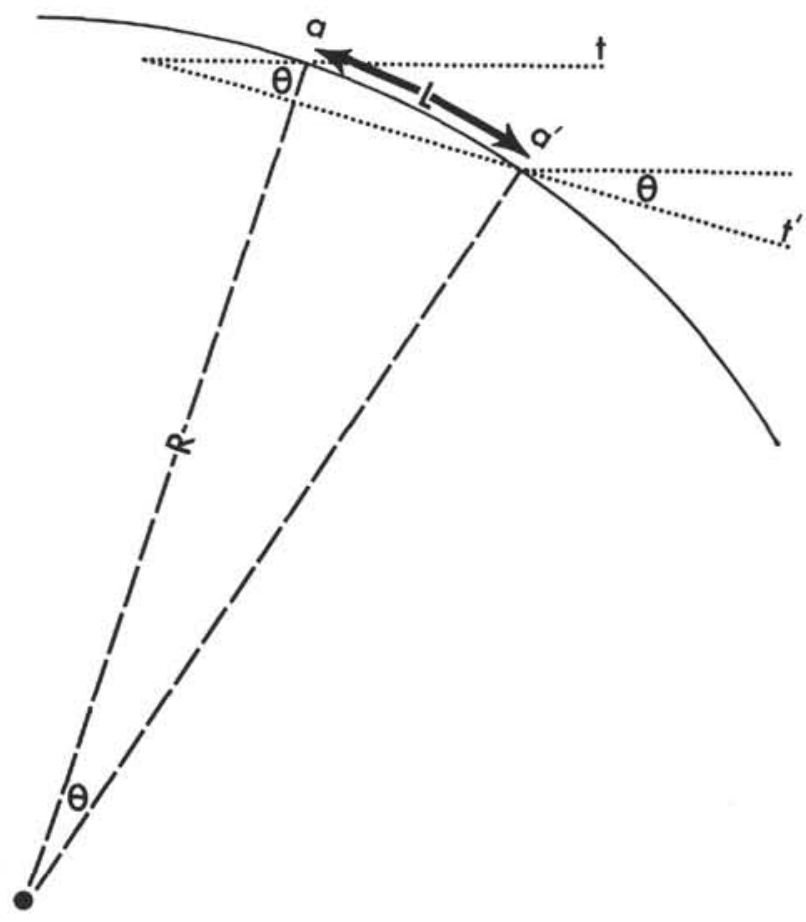

Figure 6. Schematic diagram showing the bending of the lithosphere around a constant radius of curvature $\mathrm{R}$ and the progressive tilting of the trench floor $\mathrm{t}, \ldots \mathrm{t}$ ' resulting from the displacement $\mathrm{L}$ of Point a to Point $a^{\prime}$.

$$
\frac{d L}{d t}=\frac{2 \pi R}{360} \frac{d \theta}{d t}
$$

where

$$
\frac{d \theta}{d t}
$$

is expressed in degrees per million years.

An examination of thirty-five projected topographic profiles across oceanic trenches in the Pacific (Hayes and Ewing, 1971) reveals that the converging oceanic lithosphere flexes into the trenches with an average radius of curvature of $1100 \mathrm{~km}$ for that portion of the sea floor from the crest of the outer marginal ridge to the trench axis. Measured values for the radius all lie between 800 and $1400 \mathrm{~km}$, that measured on the Hellenic Trench profile of Figure 5 approaches the minimum size.

By using this curvature, we calculate a convergence rate for the Hellenic Trench $(d L / d t)$ of $1.4 \mathrm{~cm} / \mathrm{y}-\mathrm{a}$ magnitude not considered unreasonable in terms of the residence time of the Quaternary fill beneath the trench floor.

\section{CONCLUSIONS}

The drilling results of the Glomar Challenger in the Mediterranean do not, in themselves, prove or disprove any particular hypothesis concerning the origin of the basins. However, on the other hand, these results are entirely compatible with certain particular evolutionary schemes.

For instance, we believe that the basement sampling and age dating in the western Mediterranean basins support the concept that these regions of the Mediterranean were 
created during a Lower Miocene phase of extensional rifting resulting in the rotation of small microplates.

The drilling into an inferred tectonic mélange beneath the inner wall of the Hellenic Trench and documentation of the progressive tilting of the trench strata provides, in our opinion, evidence that can be construed to indicate an active subduction of the eastern Mediterranean sea floor at a rate averaged over the last one million years of about 1.4 $\mathrm{cm} / \mathrm{y}$.

\section{REFERENCES}

Alvarez, W., 1972. Rotation of the Corsica-Sardinia Microplate. Nature. 235, 103.

Auzende, J. M., Bonnin, J., Olivet, J. L., Pautôt, G. and Mauffret, A., 1971. Upper Miocene Salt Layer in the western Mediterranean basin. Nature. 230, 82 .

Dewey, J. F. and Bird, J. M., 1970. Mountain belts and the new global tectonics. J. Geophys. Res. 75, 2625.

Fahlquist, D. A. and Hersey, J. B., 1969. Seismic refraction measurements in the western Mediterranean Sea. Bull. Instit. Océanogr. Monaco. 67 (1386), 1.

Hayes, D. E. and Ewing, M., 1971. Pacific boundary structure. In The Sea. Maxwell, A. E. (Ed.). New York (John Wiley and Sons, Intersci.). 4 (Part II), 29.

Hsü, K. J., 1968. Principle of mélanges and their bearing on the Franciscian-Knoxville Paradox. Bull. Geol. Soc. Am. $79,1063$.

1971. Franciscan mélange as a model for eugeosynclinal sedimentation and understrusting tectonics. J. Geophys. Res., 76, 1162.
Le Pichon, X., Bonnin, J. and Pautôt, G., 1970. The Gibraltar end of the Azores-Gibraltar Plate boundary: an example of compressional tectonics (Abstract). Upper Mantle Committee Symposium, Flagstaff, Arizona, July, 1970.

Le Pichon, X. and Sibuet, J. C., 1971. Histoire structurale du golfe de bascogne. Expose d'une hypothèse tectonique sur la formation du golfe. In Histoire Structural du Golfe de Gascogne. Paris. (Editions Technip).

Le Pichon, X., Pautôt, G., Auzende, J. M. and Olivet, J. L., 1971. La Méditerranée occidentale depuis l'Oligocène: schema d'evolution. Earth and Planet. Sci. Lett. 13145.

McKenzie, D. P., 1970. Plate tectonics of the Mediterranean region. Nature. 226, 239.

Montadert, L., Sancho, J., Fail, J P., Debyser, J. and Winnock, E., 1970. De L'âge tertiare de la série salifère responsable des structures diapiriques en Méditerranée Occidentale (Nord-Est des Baléares). C.R. Acad. Sci. Paris. 271, 812 .

Pitman, W. C., III and Talwani, M., 1972. Sea-floor spreading in the North Atlantic. Bull. Geol. Soc. Amer., 83,619 .

Rabinowitz, P. D. and Ryan, W. B. F., 1970. Gravity anomalies and crustal shortening in the eastern Mediterranean. Tectonophysics. 10, 585 .

Stauffer, K. W. and Tarling, D. J., 1971. Age du golfe de Gascogne: nouvelles données paléomagnetiques. In Histoire Structural du Golfe de Gascogne. Paris. (Editions Technip).

Williams, C. A. and McKenzie, D., 1971. The evolution of the North-East Atlantic. Nature. 232, 168. 